\title{
EUROPEAN PROJECTS RELATED TO ETHICAL EDUCATION IN PRIMARY AND SECONDARY SCHOOLS
}

\author{
Bruno Ćurko ${ }^{1}$, Antonio Kovačević \\ ${ }^{1}$ Faculty of Humanities and Social Sciences, \\ University of Split, Croatia \\ ${ }^{2}$ Association "Petit Philosophy", Zadar, Croatia \\ bcurko@ffst.hr; antonio.kovacevic@live.com
}

Received: 19 October 2018

Through the Erasmus + Program, in Key Activity 2 - "Strategic Partnerships in Education and Training" (KA2) - association for promotion of non-formal education, critical thinking and philosophy in practice "Petit Philosophy" has implemented or is implementing seven projects closely related to ethical education. The characteristics of these projects are that they are directed to ethical education in kindergartens and primary and secondary schools. Partners of "Petit Philosophy" in these projects were/are universities, primary and secondary schools, kindergartens, associations and institutions from thirteen countries (Austria, Germany, Slovenia, Italy, Spain, Hungary, Bosnia and Herzegovina, Greece, Ireland, the Netherlands, Slovakia, Latvia and Croatia). Project "ETHOS: Ethical Education in Primary and Pre-primary Schools for a Sustainable and Dialogic Future" is one of the first of these projects. ETHOS was successfully implemented under the Comenius Program from 20122014, and afterwards, projects under the Erasmus + KA2 followed: ETHIKA - Ethics and Values Education in Schools and Kindergartens (2014-2017), LITTLE - Learning Together to Live Together: Teachers Leading Ethical Education for an Inclusive Society (2016-2019), AVAL - Added Value Learning for Preschool Teachers \& Pedagogical Coordinators (2017-2019), COMET - A Community of Ethics Teachers in Europe (2017-2020), Integrating Ethics of Sport in Secondary School Curriculum (2017-2019), BEAGLE-Bioethical Education and Attitude Guidance for Living Environment (2018-2020) and TRACE - Traditional Children's Stories for a Common Future (2018-2020). In this article, we will briefly present the projects' activities, with particular emphasis on materials created for educators, teachers, and students.

Key words: ethical education, Erasmus + projects, ethics, formal and non-formal education 


\section{Introduction}

European Union supports educational projects through different platforms or programs. From 2007-2013 that platform was LLP COMENIUS. From 2014 to 2020 this is Erasmus+, which is EU program dedicated to education, training, youth and sport. It is open towards education, training, youth and sport organizations across all sectors of lifelong learning, including school education, further and higher education, adult education and the youth sector. Some of projects implemented through these programs are projects about ethical education, which will be our point of interest here. In this article we will shortly describe one project implemented through LLP Comenius, and seven ethical projects supported by the Erasmus+, Key Activity 2 - "Strategic Partnerships in Education and Training" (KA2). All these projects have ethical education as its primary focus, thus binding them thematically together.

\section{ETHOS - Ethical Education in Primary and Pre-primary Schools for a Sustainable and Dialogic Future}

Project ETHOS (527134-LLP 2012-SI-COMENIUS-CMP) was successfully implemented under the Comenius Program from 1 September 2012 to 31 August 2014. Project coordinator was Faculty of Theology (University of Ljubljana, Slovenia). Partners were Primary school Šmartno v Tuhinju (Slovenia), Amitié (Italy), Friedrich - Alexsander- Universität Erlangen- Nürenberg (FAU ILI - Germany), Inova 4T Tuzla (Bosnia and Herzegovina), Kirchliche Pädagogische Hochschule Graz (Austria), Scienter (Spain) and "Petit Philosophy" (Croatia). The reasons for application and implementation of the project were well explained in the application form:

"The crisis at the time has shown that the problems and challenges in Europe are not only economic or political, but also cultural and ethical. Research has shown that education in childhood is the most important phase as a basis for a healthy development of a person. An important part of that education is exactly ethical education and critical thinking that have key role in forming of ethically adult persons."

${ }^{1}$ Information from the application form of the project ETHOS. 
For these reasons, European project ETHOS was started, with a goal to introduce ethical education in kindergartens and primary schools. In the first phase of the project, a research on the user group was conducted, and five topics were chosen (respect, tolerance, responsibility, moral values and friendship). For every of these topics, creative workshops for five different age groups $(3-5,5-7,7-9,9-11,12-15$ years) were created. Altogether, 25 workshops with specific guidelines for each workshop were made and successfully piloted in schools in all partner countries (see ETHIKA project website).

For youngest target group, for children from three to five years, the ETHOS consortium created workshops (including the Manual for the teachers for each workshop) $)^{2}$ listed in Table 1.

Table 1. ETHOS Workshop/Teacher Manuals (3-5 years)

\begin{tabular}{|l|l|l|l|}
\hline \multicolumn{1}{|c|}{ Topics } & \multicolumn{1}{c|}{ Name of the workshop } & \multicolumn{1}{c|}{ Type of workshop } & \multicolumn{1}{c|}{ Author/s } \\
\hline Friendship & Good and bad in friendship & Picture thinking game & Bruno Ćurko \\
\hline Moral values & Marijana goes to kindergarten & Thinking story & Bruno Ćurko \\
\hline Respect & $\begin{array}{l}\text { Marko in kindergarten and } \\
\text { Marko at home }\end{array}$ & Thinking story & Bruno Ćurko \\
\hline Responsibility & Game of Compromise & Game & Ivana Kragić \\
\hline Tolerance & Game of Sharing & Game & Ivana Kragić \\
\hline
\end{tabular}

For children from five to seven years, the ETHIKA consortium made the workshops (including the Manual for the teachers for each workshop) $)^{3}$ listed in Table 2.

Table 2. ETHOS Workshop/Teacher Manuals (5-7 years)

\begin{tabular}{|l|l|l|l|}
\hline \multicolumn{1}{|c|}{ Topics } & Name of the workshop & Type of workshop & \multicolumn{1}{c|}{ Author/s } \\
\hline Friendship & Creature from Jupiter & $\begin{array}{l}\text { PPT Cartoon/ } \\
\text { Socratic dialogue }\end{array}$ & $\begin{array}{l}\text { Bruno Ćurko (Illustrator: } \\
\text { Marija Kragić) }\end{array}$ \\
\hline Moral values & Good Angel and Bad Imp & Thinking game & Ivana Kragić \\
\hline Respect & Stop & Thinking game & Bruno Ćurko \\
\hline $\begin{array}{l}\text { Responsi- } \\
\text { bility }\end{array}$ & Hippo and Bee & $\begin{array}{l}\text { PPT Cartoon/ } \\
\text { Socratic dialogue }\end{array}$ & $\begin{array}{l}\text { Bruno Ćurko (Illustrator: } \\
\text { Marija Kragić) }\end{array}$ \\
\hline Tolerance & Common Drawing & Game & Ivana Kragić \\
\hline
\end{tabular}

${ }^{2}$ Links to the manuals are provided in the Bibliography.

${ }^{3}$ Links to the manuals are provided in the Bibliography. 
For children from seven to nine years, the ETHIKA consortium created the workshops (including the Manual for the teachers for each workshop) $)^{4}$ listed in Table 3.

Table 3. ETHOS Workshop/Teacher Manuals (7-9 years)

\begin{tabular}{|l|l|l|l|}
\hline \multicolumn{1}{|c|}{ Topics } & Name of the workshop & Type of workshop & \multicolumn{1}{c|}{ Author/s } \\
\hline Friendship & My Best Friend & Drawing game & Ivana Kragić \\
\hline Moral values & $\begin{array}{l}\text { The Little Ones and the } \\
\text { Big Ones }\end{array}$ & Thinking story & $\begin{array}{l}\text { Story: Ivana Kragić; } \\
\text { Didactic questions and } \\
\text { instructions: Bruno Ćurko } \\
\text { and Ivana Kragić }\end{array}$ \\
\hline Respect & Story of Fluffy & Thinking game & Marina Katinić \\
\hline Responsibility & Teddy's Pear & $\begin{array}{l}\text { PPT Cartoon/ } \\
\text { Socratic dialogue }\end{array}$ & $\begin{array}{l}\text { Illustrator: Ida Sušić; } \\
\text { Story writers: Bruno } \\
\text { Curko, Marija Kragić; } \\
\text { Elena Barić, Filip } \\
\text { Majstorović (elementary } \\
\text { school students - helpers } \\
\text { in the development of } \\
\text { the story }\end{array}$ \\
\hline Tolerance & Blue Horse & $\begin{array}{l}\text { Bruno Ćurko (Illustrator: } \\
\text { Marija Kragić) }\end{array}$ \\
\hline
\end{tabular}

For the children from nine to eleven years, the ETHIKA consortium made the workshops (including the Manual for the teachers for each workshop $)^{5}$ listed in Table 4.

Table 4. ETHOS Workshop/Teacher Manuals (9-11 years)

\begin{tabular}{|l|l|l|l|}
\hline \multicolumn{1}{|c|}{ Topics } & Name of the workshop & Type of workshop & \multicolumn{1}{c|}{ Author/s } \\
\hline Friendship & What is a Friendship & $\begin{array}{l}\text { PPT Cartoon/ } \\
\text { Socratic Dialogue }\end{array}$ & $\begin{array}{l}\text { Bruno Ćurko, Ivana Kragić } \\
\text { (Illustrator: Ida Sušić) }\end{array}$ \\
\hline Moral values & What are Moral Values & $\begin{array}{l}\text { PPT Cartoon/ } \\
\text { Socratic Dialogue }\end{array}$ & $\begin{array}{l}\text { Bruno Ćurko, Ivana Kragić } \\
\text { (Illustrator: Ida Sušić) }\end{array}$ \\
\hline Respect & What Could Happen & $\begin{array}{l}\text { Game with } \\
\text { storytelling }\end{array}$ & Bruno Ćurko, Ivana Kragić \\
\hline Responsibility & What is Responsibility & $\begin{array}{l}\text { PPT Cartoon/ } \\
\text { Socratic Dialogue }\end{array}$ & $\begin{array}{l}\text { Bruno Ćurko, Ivana Kragić } \\
\text { (Illustrator: Ida Sušić) }\end{array}$ \\
\hline Tolerance & Diversity & $\begin{array}{l}\text { PPT Cartoon/ } \\
\text { Socratic Dialogue }\end{array}$ & $\begin{array}{l}\text { Bruno Ćurko, Ivana Kragić } \\
\text { (Illustrator: Ida Sušić) }\end{array}$ \\
\hline
\end{tabular}

${ }^{4}$ Links to the manuals are provided in the Bibliography.

${ }^{5}$ Links to the manuals are provided in the Bibliography. 
For the students from eleven to fifteen years, the ETHIKA consortium created the workshops (including the Manual for the teachers for each workshop $)^{6}$ listed in Table 5.

Table 5. ETHOS Workshop/Teacher Manuals (11-15 years)

\begin{tabular}{|l|l|l|l|}
\hline \multicolumn{1}{|c|}{ Topics } & \multicolumn{1}{|c|}{ Name of the workshop } & \multicolumn{1}{c|}{ Type of workshop } & \multicolumn{1}{c|}{ Author/s } \\
\hline Friendship & Defining the Friendship & Socratic dialogue & $\begin{array}{l}\text { Bruno Ćurko, } \\
\text { Marina Katinić }\end{array}$ \\
\hline Moral values & Valeria and a Pearl & Thinking story & Marina Katinić \\
\hline Respect & $\begin{array}{l}\text { Online Discussion about } \\
\text { Respect }\end{array}$ & $\begin{array}{l}\text { Online workshop/ } \\
\text { Socratic Dialogue }\end{array}$ & Bruno Ćurko \\
\hline Responsibility & $\begin{array}{l}\text { A Fully Unexpected Event in } \\
\text { Almond Street No. 31 }\end{array}$ & Thinking story & Marina Katinić \\
\hline Tolerance & Defining the Tolerance & Socratic dialogue & Bruno Ćurko \\
\hline
\end{tabular}

As a part of the project, A Manual for Teachers and Educators to Support the Development of Educational Materials and Tools for Ethical Education was also created (Schlenk et al., 2014).

\section{ETHIKA - Ethics and Values Education in Schools and Kindergartens}

The main aim of project ETHIKA (KA2-SE-31/14) was to increase the innovation and internationalization in the education sector and to strengthen the cooperation (capacity building); with critical thinking (including articulation, argumentation and rationality) raise the level of key competences and skills, emphasize active participation in society, increase the opportunities for professional development for school teachers, reinforce interaction between practices and research policy, and increase motivation and satisfaction of teachers in daily work. Project coordinator was Faculty of Theology (University of Ljubljana, Slovenia). Partner organizations in project were: Primary school Valentine Guide (Slovenia); Primary school of Šmartno (Slovenia); Kirchlich-Pädagogische Hochschule Graz (KPH, Austria); STePS (Italy); Rambla Abogados \& Asesores (Spain); Bundesverband Ethik. V (Germany); FAU Erlangen Nuremberg - OR (Germany) and

\footnotetext{
${ }^{6}$ Links to the manuals are provided in the Bibliography.
} 
"Petit Philosophy" (Croatia). Project ETHIKA started on 1 September 2014 and ended on 1 August 2017. ${ }^{7}$ All planned activities in the project were successfully implemented. Similar as in project ETHOS, as a first project activity, analysis of the state of the art was conducted with development of methodology, directing focus on needs of teachers and educators in the fields of ethics and values education in schools. The results of this research included state of the art in participating countries in the Ethical and Value Education (EVE). Through its duration, project organized few surveys and focus groups, all with the main aim to learn what teachers in schools expect from ETHIKA project. All results are available in the document Ethics and Value Education - Existing State of the Art and User Needs Analysis. Summary Report (Schlenk et al., 2015). For example, in online survey a total of 301 teachers and educators participated. Responses came from all project partner countries in Europe and - via the questionnaire in Spanish - even from several countries in South America. Most responses were from Croatia (80) and Slovenia (75), followed by Austria (52), Italy (30), Spain (27), and Germany (21). The distribution from countries in South America is: Peru (6), Argentina (4), Mexico (3), Columbia (1), Guatemala (1), and Venezuela (1). One of the questions was about participants' experiences with the Ethical and Value Education (Table 6).

Table 6. Experiences with EVE (Schlenk et al., 2015, 12)

\begin{tabular}{|l|c|c|}
\hline \multirow{2}{*}{\multicolumn{1}{|c|}{ Question }} & \multicolumn{2}{c|}{ Answer (\%) } \\
\cline { 2 - 3 } & Yes & No \\
\hline Prepared by initial teacher training? & 38.2 & 55.1 \\
\hline Supplementary teacher training courses offered? & 42.5 & 44.9 \\
\hline Attended one or more teacher training courses? & 39.9 & 60.1 \\
\hline Self-Study? & 77.4 & 22.6 \\
\hline Ready for teaching EVE? & 65.8 & 30.2 \\
\hline Comfortable with teaching EVE? & 74.4 & 22.9 \\
\hline
\end{tabular}

Teachers from online surveys and focus groups claimed that they need educational materials and tools for specific topics in their EVE education (Table 7).

\footnotetext{
${ }^{7}$ Information from the ETHIKA application form.
} 
Table 7. Top ten topics for educational materials and tools according to the participants in the online surveys and focus groups (Schlenk et al., 2015, 9-16)

\begin{tabular}{|l|l|}
\hline \multicolumn{2}{|c|}{ Topics for educational materials and tools } \\
\hline "Definitely agree" & "Definitely agree" and "rather agree" \\
\hline 1. Responsibility & 1. Justice \\
2. Respect & 2. Responsibility \\
3. Self-esteem & 3. Dialogue \\
4. Justice & 4. Respect \\
5. Conflict resolution & 5. Conflict Resolution \\
6. Honesty & 6. Relationships \\
7. Dialogue & 7. Moral values \\
8. Critical Reflection & 8. Honesty \\
9. Co-operation & 9. Self-esteem \\
10. Moral values & 10. Co-operation \\
\hline
\end{tabular}

Participants of the surveys and focus groups also answered questions about methods they want to use in EVE, on what kind of media they want their educational materials for EVE, etc. The Summary Report (Schlenk et al., 2015) provides us with a good insight at the state of the art, expectations and willingness of teachers and educators in Ethical and Value Education in Italy, Germany, Austria, Slovenia and Croatia.

Concerning the results in the Ethics and Value Education - Existing State of the Art and User Needs Analysis (Schlenk et al., 2015), the consortium prepared 30 educational materials and tools, together with manual for each educational material (Table 8). ETHIKA Educational Tools are available in English, Spanish, German, Italian and Slovenian. ${ }^{8}$

\footnotetext{
${ }^{8}$ Links to the Educational Tools are provided in the Bibliography.
} 
Table 8. The list of ETHIKA Educational Tools

\begin{tabular}{|c|c|c|c|c|}
\hline Topic & $\begin{array}{l}\text { Name of the } \\
\text { workshop }\end{array}$ & $\begin{array}{c}\text { Age } \\
\text { group }\end{array}$ & $\begin{array}{c}\text { Type of } \\
\text { workshop }\end{array}$ & Author/s \\
\hline Justice & Tomato's feelings & $3-5$ & Game & $\begin{array}{l}\text { Bruno Ćurko, } \\
\text { Marija Kragić }\end{array}$ \\
\hline Justice & Sad broccoli & $5-7$ & $\begin{array}{l}\text { PPT Cartoon / } \\
\text { Socratic } \\
\text { dialogue } \\
\end{array}$ & $\begin{array}{l}\text { Bruno Ćurko, } \\
\text { Marija Kragić }\end{array}$ \\
\hline Justice & Unfair rain & $7-9$ & Thinking story & $\begin{array}{l}\text { Bruno Ćurko, } \\
\text { Marija Kragić }\end{array}$ \\
\hline Justice & What is justice? & $9-11$ & $\begin{array}{l}\text { PPT Cartoon / } \\
\text { Socratic } \\
\text { dialogue }\end{array}$ & Ivana Kragić \\
\hline Justice & $\begin{array}{l}\text { The mathematics } \\
\text { exam }\end{array}$ & $11-14$ & Thinking story & Bruno Ćurko \\
\hline Respect & $\begin{array}{l}\text { The speeches } \\
\text { round }\end{array}$ & $3-5$ & Game & $\begin{array}{l}\text { M. Begoña Arenas, } \\
\text { Eduardo Linares }\end{array}$ \\
\hline Respect & Elf's box & $5-7$ & Game & Petra Ivanušič \\
\hline Respect & $\begin{array}{l}\text { Why do we need to } \\
\text { respect others? }\end{array}$ & $7-9$ & $\begin{array}{l}\text { PPT Cartoon / } \\
\text { Socratic } \\
\text { dialogue }\end{array}$ & $\begin{array}{l}\text { Bruno Ćurko, } \\
\text { Marija Kragić }\end{array}$ \\
\hline Respect & Step forward & $9-11$ & Thinking game & $\begin{array}{l}\text { Mateja Štritof, Hajdeja } \\
\text { Praprotnik, Urša Mulej, } \\
\text { Anja Pavlin, Vlasta } \\
\text { Tacer, Mojca Jurca }\end{array}$ \\
\hline Respect & $\begin{array}{l}\text { The debate and the } \\
\text { jury }\end{array}$ & $11-14$ & Debate & Ivana Kragić \\
\hline Responsibility & Pumpkin signs & $3-5$ & Game & Ivana Kragić \\
\hline Responsibility & Story about Peter & $5-7$ & Short story & Ivona Matana \\
\hline Responsibility & A girl and a dog & $7-9$ & Thinking poem & Ivana Kragić \\
\hline Responsibility & Superheroes & $9-11$ & $\begin{array}{l}\text { PPT Cartoon / } \\
\text { Socratic } \\
\text { dialogue }\end{array}$ & Ivana Kragić \\
\hline Responsibility & $\begin{array}{l}\text { A poem for a better } \\
\text { world }\end{array}$ & $11-14$ & Thinking game & Sabina Slana Cvikl \\
\hline Self esteem & Puppet's problems & $3-5$ & Game & Marija Kragić \\
\hline Self esteem & $\begin{array}{l}\text { Daddy is a } \\
\text { superhero }\end{array}$ & $5-7$ & Game & $\begin{array}{l}\text { Eduardo Linares, } \\
\text { M. Begoña Arenas }\end{array}$ \\
\hline Self esteem & Try to find positive & $7-9$ & Thinking game & Tanja Grže \\
\hline
\end{tabular}




\begin{tabular}{|l|l|c|l|l|}
\hline \multicolumn{1}{|c|}{ Topic } & \multicolumn{1}{|c|}{$\begin{array}{c}\text { Name of the } \\
\text { workshop }\end{array}$} & $\begin{array}{c}\text { Age } \\
\text { group }\end{array}$ & \multicolumn{1}{c|}{$\begin{array}{c}\text { Type of } \\
\text { workshop }\end{array}$} & \multicolumn{1}{c|}{ Author/s } \\
\hline Self esteem & Just be you! & $9-11$ & Thinking game & $\begin{array}{l}\text { Ivana Kragić, } \\
\text { Svenja Pokorny }\end{array}$ \\
\hline Self esteem & Picture workshop & $11-14$ & Thinking game & $\begin{array}{l}\text { Adapted by Bruno Curko } \\
\text { and Marija Kragić }\end{array}$ \\
\hline $\begin{array}{l}\text { Conflict } \\
\text { resolution }\end{array}$ & Who is faster? & $3-5$ & Game & Ivona Matana \\
\hline $\begin{array}{l}\text { Conflict } \\
\text { resolution }\end{array}$ & Sign choosing & $5-7$ & Game & Ivana Kragić \\
\hline $\begin{array}{l}\text { Conflict } \\
\text { resolution }\end{array}$ & $\begin{array}{l}\text { We all like our } \\
\text { logo }\end{array}$ & $7-9$ & Game & $\begin{array}{l}\text { Eduardo Linares, } \\
\text { M. Begoña Arenas }\end{array}$ \\
\hline $\begin{array}{l}\text { Conflict } \\
\text { resolution }\end{array}$ & Making peace & $9-11$ & Thinking game & Antonia Krajina \\
\hline $\begin{array}{l}\text { Conflict } \\
\text { resolution }\end{array}$ & $\begin{array}{l}\text { Listening and } \\
\text { communication } \\
\text { skills }\end{array}$ & $11-14$ & Thinking game & Ivana Kragić \\
\hline $\begin{array}{l}\text { Ethical } \\
\text { actions }\end{array}$ & $\begin{array}{l}\text { Overcoming } \\
\text { obstacles }\end{array}$ & $3-5$ & Game & Marija Kragić \\
\hline $\begin{array}{l}\text { Ethical } \\
\text { actions }\end{array}$ & Cooperative games & $5-7$ & Game & Melita Peskar \\
\hline $\begin{array}{l}\text { Ethical } \\
\text { actions }\end{array}$ & Civic action & $7-9$ & $\begin{array}{l}\text { Socratic } \\
\text { dialogue }\end{array}$ & Marija Kragić \\
\hline $\begin{array}{l}\text { Ethical } \\
\text { actions }\end{array}$ & $\begin{array}{l}\text { Code of ethics for } \\
\text { volunteers }\end{array}$ & $9-11$ & Game & Mojca Jurca \\
\hline $\begin{array}{l}\text { Ethical } \\
\text { actions }\end{array}$ & better world & $11-14$ & Game & Vlasta Tacer \\
\hline
\end{tabular}

Also, the ETHIKA consortium prepared Ethics and Values Education Curriculum Proposals and Training Courses for Teachers - Ethics and Values Education in Schools and Kindergartens (Ćurko et al., 2017). Curriculum proposal includes chapters such as: "Approaches to ethics and values education", "Curriculum and the training of teachers and educators: Themes, development, and implementation", "Guidelines on the implementation of teacher training based on ETHIKA project", "Study guide to ethics and values education using ETHIKA materials", "ETHIKA training courses proposals (including kindergarten (3-5 years) and school levels (from 5-9 and 9-14 years)), "Evaluation in the field of ethics and values education", "Existing models, 
curriculums and opportunities for teachers and educators in participating countries", "Curriculum proposals for ethics and values education", "Ethics and values curriculum approaches", etc.

For the end of the project, the ETHIKA consortium aimed to have an impact on decision-makers in the EU and participating countries. Thus, the consortium created Ethics and Values Education in Schools and Kindergartens - Policy Paper (Pfeil et al., 2017).

\section{ETHIKA - Ethics and Values Education in Schools and Kindergartens Implementation}

In above mentioned Erasmus+ project ETHIKA, the piloting of workshops was not planned. That is why the "Petit Philosophy", with the support of Croatian Ministry of Science and Education, implemented workshops from ETHIKA project in Croatian schools and kindergartens. At the beginning of the Croatian ETHIKA project, total of 37 teachers and educators were trained for early ethics and value education. The project involved 667 direct users, students from the first to the eighth grade of primary school (6-14 years) and nursery children (3 to 6 years old). The students directly participated in 5 workshops envisaged by the project. The workshops were divided by different topics (fairness, responsibility, self-reliance, respect, and conflict resolution) and age groups $(3-5,5-7,7-9,9-11,11-14)$. These workshops have been conducted through interactive work using the following methods: synergistic dialogue, visual thinking, didactic games, active reading, creative tasks of developing various objects related to the subject, etc. Throughout the abovementioned methods and apart from adopting new concepts, the disciples also developed the responsibility for others (according to peers and adults), the ability to resolve conflicts with dialogue, the ability to recognize the causes of conflict, the ability to understand and accept the other and their different opinions. Participants also raised the level of curiosity, independence, and the ability to logically connect and conclude. After the implementation of the workshops, the students actively participated in the design, organization and implementation of ethical actions. With these activities, the students showed that they were aware of the needs of their community and demonstrated a great level of creativity and self-initiative in problem solving. 
"Petit Philosophy" was the coordinator of project. Partners where Elementary School Voltino, Zagreb; Elementary School Bukovac, Zagreb; Elementary School dr. Vinka Žganca, Zagreb; Elementary School Josip Pupačić, Omiš; Elementary School o. Petra Perice, Makarska; Elementary School Šime Budinić, Zadar; Elementary School Zadarski otoci, Zadar; Kindergarten Žirafa, Rijeka; Elementary School Slakovci, Slakovci; Kindergarten Žuto Pače, Zadar; Elementary School Valentin Klarin, Preko, and Zadar County (co-financing the project activities). Project was implemented from 1 December 2016 to 31 August 2017.

\section{AVAL - Added Value Learning for Preschool Teachers and Pedagogical Coordinators}

AVAL (2017-1-ES01-KA201-038113) is a project similar to ETHIKA and ETHOS, with the difference that the AVAL target group is focused on preschool children, preschool teachers and pedagogical coordinators. The project addresses the field of ethics and values education and focuses on empowering Early Childhood Care and Education (ECEC) and primary school professionals. Project AVAL encourages children to learn about values using critical thinking approach based on 3 pillars: ethic values (personal values - "self"); democratic and societal values (as we live in a society - "self and the others"; and environmental values (as we live on the planet Earth). Project started on 1 September 2017, and will be finished on 31 August 2019. Project coordinator is AMEI-WAECE - World Association of Early Childhood Educators (Spain). AVAL project partners are Faculty of Theology (University of Ljubljana, Slovenia), STePS (Italy), ITC - Innovation Training Center, S.L (Spain), Institut für Lern-Innovation (Germany), Budapest University of Technology and Economics (Hungary), LTD-CARDET (Cyprus), Militos Consulting S.A. (Greece), Fundatia Centrul Educational Spektrum (Romania) and association "Petit Philosophy" (Croatia). ${ }^{9}$

Main goals of the project are the implementation of a transnational curriculum for the partners' countries and creation of the innovative practices and approaches in preschool and primary school education. First part of the project (first intellectual output) was finalized with the Short Report on the State of the Art of Values Education Learning for

\footnotetext{
${ }^{9}$ Information from the AVAL application form.
} 
ECEC and Primary Education Teachers (Sánchez-Igual et al., Short Report). AVAL project resulted in 46 workshops. ${ }^{10}$ Workshops are thematically organized in three pillars: Ethic values (personal values - the self); Democratic and societal values (as we live in society - the self and others) and Environmental values (we live on the planet Earth). For youngest kids (0-3 years) there are six workshops: Creativity, Family, Exploring Animals, Curiosity, Comfort, and Exploring Nature. For kids from 3 to 6 years there are 20 different workshops: Generosity, Conflict Resolution, Outdoor Time, Self-Control, Friendship, Sustainability, Responsibility, Justice, Clean Water, Relation of Ethics and Aesthetics, Dialogue, Health, Honesty, Respect, Exploring Plants, Self-Expression, Diversity, Self-Sustainable Gardens, Courage, and Culture. For kids from 7 to 11 years there are also 20 workshops: Self-Esteem, Active Citizenship and Democratic Culture, Pollution, Responsibility, Empathy, Living Environment, Self-Care, Children's Rights, Environmental Protection, Persistence, Fairness, Recycling, Problem Solving, Moral Dilemmas, Animals in Captivity, Work Ethics, Freedom, Trees and the Oxygen, Independence, Cooperation and Mutual Aid. Information on how to organize these workshops and on the methods that can be used in AVAL workshops can be found in AVAL Handbook for Teachers and Parents. A final plan is to create an online center on ethics, values, and critical thinking education by the end of the project.

\section{LITTLE - Learning Together to Live Together: Teachers Leading Ethical Education for an Inclusive Society}

The project LITTLE (2016-1-IE01-KA201-016868) was also funded by the Erasmus + program, and gathered 4 partners with common aim of increasing innovation and internationalization in the education sector and strengthening cooperation (capacity building). With critical thinking (including articulation, argumentation and rationality, and presentation of how one view leads to increased achievement) LITTLE aims to raise the level of key competences and skills, emphasize active participation in society, increase opportunities for professional development for school teachers, reinforce interaction between practice, research and policy and increase motivation and satisfaction of teachers

${ }^{10}$ Link to the training materials is provided in the Bibliography. 
in their daily work. Project coordinator for LITTLE project is Educate Together (Ireland). Partners in project are Faculty of Theology (University of Ljubljana, Slovenia), STePS (Italy) and "Petit Philosophy" (Croatia). Project started on 1 September 2016 and will finish on $31 \mathrm{Au}-$ gust 2019. ${ }^{11} \mathrm{~A}$ few of the main aims are to promote innovative practices and internationalization between sectors of ethical education, strengthen the professional development of teachers and educators in the field of ethical education and raise the confidence of teachers so that they could develop their own educational materials and apply ethical education in the subjects they are teaching. One of the main activities of the LITTLE project is creating online course of methodology for ethical education for teachers and educators (see the LITTLE online course). The free online course is available in four languages (Croatian, Slovenian, Italian and English) and contains six modules: Introduction to Ethical Education; Critical and Creative Thinking; Ethical Decision Making and Ethical Dilemmas; Holistic and Biographical Learning; Managing Conflict and Facilitating Dialogue on Controversial Issues; The Ethics of Care.

Also, the LITTLE consortium created the LITTLE Guide for Teachers of Ethical Education (Centa et al., The LITTLE Guide). Main topics in the Guide are: What is ethical education? About active learning classrooms; Co-created teaching and learning approach; Higher order (thinking) skills and ethical issues; How to engage students and make them the centre of ethical education; How to address ethical issues in different subject areas of education?; How to examine ethical challenges in contemporary societies? Ethical education in the context of EU values, etc. Also, one of the products of project is a Letter of Intent for decision makers named The Case for Ethical Education. Bridging the Gap between Practice and Policy in Europe (Centa et al., The Case for Ethical Education). This letter mainly aims to help the policy makers understand the necessity of ethical education in formal and non-formal education.

\section{Integrating Ethics of Sport in Secondary School Curriculum}

The project Integrating Ethics of Sport in Secondary School Curriculum (Erasmus+ KA2 Project 2017-1-HR01-KA201-035428) is of an interdisciplinary nature and is primarily intended for professors of

\footnotetext{
${ }^{11}$ Information from the application form of LITTLE project.
} 
a series of subjects who may include topics related to ethics of sport in the course of their subject. Topics include dealing with specific moral problems, such as ethics and philosophy, religion, politics and economics (racism, corruption, betting...), sociology (racism, gender equality), chemistry and biology (doping, Paralympics...), physical education, art (fairness of aesthetic sports scoring), etc. Such topics can be integrated in the existing curricula using various moral problems of ethics of sport. Project gathers five partners from four different countries: Elektrostrojarska škola Varaždin, Croatia; Friedrich-Wöhler-Gymnasium, Singen, Germany; Istituto d'Istruzione Superiore "Ancel Keys", Castelnuovo Cilento, Italy; "Petit Philosophy", Zadar, Croatia; and Faculty of Theology, Institute of Philosophy and Ethics, University of Ljubljana, Slovenia. Project started on 7 November 2017 and will be finished on 6 November 2019. Main goals of the project are: to enhance the provision of the ethics education at the ISCED 3 (upper-secondary) level; wider integration of the ethics of sport contents into the school curriculum in full compliance with the cross-curricular approach, and to improve the competencies of secondary school teachers that are needed for more effective and sustainable ethics of sport-based educational provision/teaching at the upper-secondary level. ${ }^{12}$ The expected result of this project is the curriculum framework of the Ethics of Sport; methodology guidelines for teaching Ethics of Sport under the secondary school curriculum, and web-based thematic platform (Open Education Resource) on educational provision of Ethics of Sport. These results are based on four topics organized in modules.

Module 1:

- Intentional rule-breaking and fair-play in sports

- Golden rule: Respect the others to be respected while practicing the sport

- Fair-play and "respect for the game"

- "Rules have strength": once the player understands the rules he/ she cannot act contrary to them, etc.

Module 2:

- Virtues and flaws in sport

${ }^{12}$ Information from the application form of the project Integrating Ethics of Sport in Secondary School Curriculum. 
- Virtue - acquired and persisting character trait or disposition that represents the basis for moral appreciation with main questions: Are these virtues the same for individual and team sports? Is there a virtue that is a virtue in all of the sports? Is there a virtue that is a virtue in "normal" life and in all of the Sports?, etc.

Module 3:

- Gender equality in sports

- Sex-label and gender role

- Gender identity

- Gender equality in different sports

- Transgender athletes and their place in sport

Module 4:

- Racism in Sport; different types of racism

- Stereotypes and racist myths e.g. "natural talent"

- Racism in our surroundings

- Solutions to racism in sport

\section{COMET - A Community of Ethics Teachers in Europe}

The project Community of Ethics Teachers in Europe (2017-1NL01-KA201-035219) aims at overcoming curricular differences through digital innovation in order to promote the acquisition of skills and competences of European ethics teachers. One of the main aims of the COMET project is connecting high schools teachers of Ethics from all across the European Union. The COMET consortium tries to do this with mapping the various ethics curricula in European secondary schools by means of an online interactive platform (see the web page of the project). Through the COMET project, the consortium will research the various European ethics curricula by categorizing different approaches in Ethics curricula in European secondary schools. The COMET consortium claims:

"Ethics education plays an integral role in the fostering of European values. However, the subject of ethics is studied in schools within a wide variety of curricula across Europe, ranging from moral philosophy and religious education to world view education and general philosophy. This fragmentation of curricula, along with a fragmentation of pedagogical methods and goals, 
inhibits the opportunities for exchanges of best practices and mutual learning, which are two of the objectives of the strategic framework for European cooperation in education and training (ET2020)."13

Project coordinator is Stichting Katholieke Universiteit Brabant (the Netherlands). Partners in project are Zofijini Ljubimci - Drustvo za razoj humanistike (Slovenia), Matej Bel University (Slovakia), Gymnasium Weilheim (Germany), Stichting BOOR (the Netherlands) and "Petit Philosophy" (Croatia). Project started on 1 September 2017 and will end on 31 August 2020.

\section{BEAGLE - Bioethical Education and Attitude Guidance for Living Environment}

The project Bioethical Education and Attitude Guidance for Living Environment (BEAGLE, 018-1-HR01-KA201-047484) brings together international partners from the Mediterranean Pool with the aim of promoting open education and innovative educational practices.

"The idea that drives this project forward is that recent rapid development of technology requires a new approach to teaching - education systems and professors are struggling to keep up with new technical capabilities, and the purpose of the project is to provide educators with a methodological framework and guidelines that will help them with introducing innovative practices in the contemporary environment. On the other hand, same as teachers, students are trying to keep up with the contemporary surroundings, surroundings which suppress the relationship with the environment, more precisely with the nature. BEAGLE's partners are motivated to believe that bioethical values and critical thinking are crucial elements, now more than ever, of the development of a democratic, pluralistic, ecologically aware open society, which is why the focus of general education should be shifted on these elements. The BEAGLE project, therefore, as the primary user of this project sees students (6 to 18 years old) equally as teachers.

The purpose of the project is to develop concrete guidelines for bioethical education that will assist teachers in implementing higher order skills, especially critical thinking. Additionally, with the development of educational materials and manuals, BEAGLE will further improve the development of the teaching staff, and the available materials will also address the practical application of educational strategies - such as organizing and conducting bioethical workshops, developing Socratic dialogue, etc. Given that the project is devoted equally to students and teachers, the focus will be on the conduct of

\footnotetext{
${ }^{13}$ Information from the COMET application form.
} 
bioethical workshops with the aim of developing bioethical values and critical thinking in students. Furthermore, BEAGLE will develop a transnational school curriculum for bioethical education in which will revise the current representation of bioethical values and critical thinking in schools. Ultimately, the development of the BEAGLE online archive and bioethical education network will connect the teachers and educators across an open platform that will optimize the exchange of experiences and encourage faster implementation of innovative methods." (Kovačević, BEAGLE - About the project)

Project started on 3 September 2018 and will be finished on 2 September 2020. Project coordinator for BEAGLE project is "Petit Philosophy" (Croatia). Partners in project are Faculty of Theology (University of Ljubljana, Slovenia); STePS (Italy), Centre for Integrative Bioethics (University of Split, Croatia) and InternetNow! (Greece).

For now, the document titled The Teacher Guidelines in Early Bioethical Education is created (Centa et al., 2019). These guidelines provide a short instruction to teachers involved in early education (6-14 years) on the idea, goals, and the current state of bioethical education in Croatia, Greece, Italy, and Slovenia. By the end of the project, consortium will develop eight different workshops on the relationship between nature and man. There will be four different approaches: through art, dialogue, digital media, and holistic approach. From these workshops, consortium will create four picture books for kids from 6-11 years.

\section{TRACE - Traditional Children's Stories for a Common Future}

Traditional children's stories for a common future-TRACE project (2018-1-HR01-KA201-047483) is focused on raising awareness of the importance of Europe's cultural heritage through education and lifelong learning, supporting skills development, social inclusion, and critical thinking. New participatory and intercultural approaches to heritage, as well as educational initiatives aimed at fostering intercultural dialogue involving teachers and pupils from an early age will be promoted. The main aim is to promote and get to know European cultural heritage through traditional children stories from partners' countries. Traditional children stories can be seen as an integral part of Europe. They express Europe's history, and influence it in return. There is an abundance of children stories in Europe, based on myths and legends, in every partner country such as Greek myths, Slavic legends, fairytales 
by the Grimm brothers or Hans Christian Andersen, just to name a few most famous ones. Numerous variations are based on these stories. The project's aim is to show the children the value, variety, and richness of the European literature. Also, by promoting stories from different countries we are raising an awareness of multiculturalism. Project coordinator is National and University Library in Zagreb (Croatia), and partners are Elementary school Josip Pupačić (Omiš, Croatia), Beidriba Radosas Idejas / Society Creative Ideas (Latvia), Euro-Arab Foundation - FUNDEA (Spain), University of the Peloponnese, Department of Social \& Training Policy (Greece) and "Petit Philosophy" (Croatia). Project started on 1 September 2018 and will be finished on 31 August 2020.

Consortium of TRACE project chooses three traditional children stories from each partner's country. Each story has to have a strong ethical message. For each of the chosen stories workshop for raising critical thinking will be developed. Also, teacher guidelines for all stories (workshops) will be created. At the end of the project TRACE eplatform for traditional European children stories will be opened and in this way archive for traditional European children stories will be established.

\section{Conclusion}

Ethical education is something that we need in modern/digital world. Even policy makers are conscious of that fact. European Union through the Erasmus + platform supports projects that are strongly connected with ethical education. Implementation of this kind of projects had more benefits for educational researchers, teachers, students, and parents. Different kinds of institutions (universities, non-government organizations, schools, kindergartens, companies) combine their knowledge and efforts in creating new educational methodologies, materials, tools, and educational policy. These kinds of projects are crucial in developing formal and non-formal education, as they connect formal and non-formal educational institutions. This kind of innovative approaches, cooperation, and project building capacities improve educational system in global. If we talk just about projects mentioned in this article, we can conclude that more than 100 new ethical materials and tools were created that are freely available to teachers, parents, and experts in 
education. Significant number of curriculum proposals, teacher manuals, and teacher training tools were created in the process. New and innovative approaches and methodologies for direct work with children and youth were developed. Even small influence on politicians was noted. Also, through these projects some new theories were developed, for example, concept of Ethical and Value Education (EVE). As Vojko Strahovnik states

"The term ethics and values education (EVE) applies to all aspects of education which either explicitly or implicitly relate to ethical dimensions of life and are such that can be structured, regulated and monitored with appropriate educational methods and tools. Among the main aims of EVE are the following: to stimulate ethical reflection, awareness, responsibility, and compassion in children, provide children with insight into important ethical principles and values, equip them with intellectual capacities (critical thinking and evaluation, reflection, discovery, understanding, decision-making, non-cognitive abilities like compassion) for responsible moral judgment, to develop approaches to build a classroom or school environment as an ethical community, and to reflectively situate individuals into other local and global communities with a mission to contribute to the common good." (Strahovnik, in: Ćurko, 2015, 6)

\section{Bibliography}

AVAL Handbook for Teachers and Parents. Available at: https://files.odl.org/aval/en/ENGLISH_Handbook.pdf

AVAL Training materials. Available at: http://valueseducation.odl.org/training-materials-in-english/

Mateja Centa, Bruno Ćurko, Laura Dooley, Sandra Irwin-Gowran, Zoran Kojčić, Ivana Kragić, Svenja Pokorny, Pier Giacomo Sola, Vojko Strahovnik, Fionnuala Ward, The LITTLE guide for teachers of ethical education. Available at: http://www.ethicaleducation.eu/resource2.htm

Mateja Centa, Bruno Ćurko, Ivana Kragić, Sandra Irwin-Gowran, Svenja Pokorny, Pier Giacomo Sola, Vojko Strahovnik, The case for ethical education. Bridging the gap between practice and policy in Europe. Available at: http://www.ethicaleducation.eu/LITTLE_Policy_Paper_EN.pdf

Mateja Centa, Bruno Ćurko, Josip Guć, Antonio Kovačević, Marija Kragić, Maddalena Nicoletti, Pier Giacomo Sola, Giannis Stamatellos, Vojko Strahovnik, Nikos Vasilakos (2019), Teacher guidelines in early bioethical education. Available at: https://beagleproject.eu/wp-content/uploads/2019/04/O1-TeacherGuidelines-in-Early-Bioethical-Education.pdf 
COMET project website: https://ethics.community/

Bruno Ćurko, Franz Feiner, Stanko Gerjolj, Janez Juhant, Kerstin Kreß, Valentina Mazzoni, Luigina Mortari, Svenja Pokorny, Evelyn Schlenk, Vojko Strahovnik (2015), Ethics and values education - Manual for teachers and educators, Ljubljana: Project: ETHIKA - Ethics and values education in schools and kindergartens.

Bruno Ćurko, Evelyn Schlenk, Franz Feiner, Svenja Pokorny, Peir Giacomo Sola, Mateja Centa, Eduardo Linares, Begoña Arenas, Marija Kragić, Vojko Strahovnik (2017), Ethics and values education curriculum proposals and training courses for teachers - Ethics and values education in schools and kindergartens. Available at: http://www.ethics-education.eu/resources/ETHIKA_EVE\%20Curriculum_Proposal_EN.pdf

ETHIKA Educational tools. Available at: http://www.ethics-education.eu/tools/index.htm

ETHIKA project website: http://www.ethics-education.eu

ETHOS Workshop/Teacher manuals (3-5 years):

- Good and bad in friendship: http://www.ethics-education.eu/tools/D9 Friendship_3-5_Teacher\%20Manual_Good_and_bad_in_friendship.pdf

- Marijana goes to kindergarten: http://www.ethics-education.eu/tools/D9 Moral\%20values_3-5_Teacher\%20Manual_Marijana_goes_to_kindergarten.pdf

- Marko in kindergarten and Marko at home: http://www.ethics-education. eu/tools/D9_Respect_3-5_Teacher\%20Manual_Marko_in_kindergarten and_Marko_at_home.pdf

- Game of Compromise: http://www.ethics-education.eu/tools/D9_Responsibility_3-5_Teacher\%20Manual_Game\%20of\%20Compromise.pdf

- Game of Sharing: http://www.ethics-education.eu/tools/D9_Tolerance_35_Teacher\%20Manual_Game $\% 20$ of $\% 20$ Sharing.pdf

ETHOS Workshop/Teacher manuals (5-7 years):

- Creature from Jupiter: http://www.ethics-education.eu/tools/D9_Friendship_5-7_Teacher\%20Manual_Creature\%20from\%20Jupiter.pdf; PPT Cartoon: http://www.ethics-education.eu/tools/D7_Friendship_5-7 Presentation_Creature\%20from\%20Jupiter.pptx

- Good Angel and Bad Imp: http://www.ethics-education.eu/tools/D9 Moral\%20Values_5-7_Teacher\%20Manual_Good $\% 20$ Angel $\% 20$ and $\% 20$ Bad\%20Imp_game.pdf

- Stop: http://www.ethics-education.eu/tools/D9_Respect_5-7_Teacher\%20 Manual_Stop.pdf 
- Hippo and Bee: http://www.ethics-education.eu/tools/D9_Responsibility 5-7_Teacher\%20Manual_Hippo\%20and\%20Bee.pdf; PPT Cartoon here: http://www.ethics-education.eu/tools/D7_Responsibility_5-7_Presentation_Hippo_and_Bee.pptx

- Common Drawing: http://www.ethics-education.eu/tools/D9_Tolerance 5-7_Teacher\%20Manual_Common\%20Drawing.pdf

ETHOS Workshop/Teacher manuals (7-9 years):

- My Best Friend: http://www.ethics-education.eu/tools/D9_Friendship_79_Teacher\%20Manual_My\%20Best $\% 20$ Friend.pdf

- The Little Ones and the Big Ones: http://www.ethics-education.eu/tools/ D9_Moral\%20Values_7-9_Teacher\%20Manual_The\%20Little\%200nes \%20and\%20the\%20Big\%20Ones.pdf; Thinking story: http://www.ethicseducation.eu/tools/D7_Moral\%20Values_7-9_Story_The\%20Little $\% 200$ nes\%20and\%20the\%20Big\%20Ones.pdf

- Story of Fluffy: http://www.ethics-education.eu/tools/D9_Respect_7-9 Teacher\%20Manual Story\%20of\%20Fluffy.pdf; Thinking story: http://www. ethics-education.eu/tools/D7_Respect_7-9_Story_Story\%20of\%20Fluffy.pdf

- Teddy's Pear: http://www.ethics-education.eu/tools/D9_Responsibility_7-9_Teacher\%20Manual_Teddy's\%20Pear.pdf; PPT Cartoon: http:// www.ethics-education.eu/tools/D7_Responsibility_7-9_Presentation Teddy's\%20Pear.pptx

- Blue Horse: http://www.ethics-education.eu/tools/D9 Tolerance 7-9 Teacher\%20Manual_Blue\%20Horse.pdf; PPT Cartoon: http://www.ethics-education.eu/tools/D7_Tolerance 7-9 Presentation_Blue\%20Horse. pptx

ETHOS Workshop/Teacher manuals (9-11 years):

- What is a Friendship: http://www.ethics-education.eu/tools/D9_Friendship_9-11_Teacher\%20Manual_Friendship.pdf; PPT Cartoon: http://www. ethics-education.eu/tools/D7_Friendship_9-11_Presentation_Friendship. pptx

- What are Moral Values: http:/www.ethics-education.eu/tools/D9 Moral\%20Values_9-11_Teacher\%20Manual_Moral\%20Values.pdf; Cartoon: http://www.ethics-education.eu/tools/D7_Moral\%20Values_9-11_ Presentation_Moral\%20Values.pptx

- What could Happen: http://www.ethics-education.eu/tools/D9_Respect_911_Teacher\%20Manual_What\%20Could\%20Happen.pdf

- What is Responsibility: http://www.ethics-education.eu/tools/D9_Responsibility_9-11_Teacher\%20Manual_Responsibility.pdf; PPT Cartoon: http://www.ethics-education.eu/tools/D7_Responsibility_9-11_Presentation_Responsibility.pptx 
- Diversity: http://www.ethics-education.eu/tools/D9_Tolerance_9-11 Teacher\%20Manual_Diversity.pdf; PPT Cartoon: http://www.ethics-education.eu/tools/D7_Tolerance_9-11_Presentation_Diversity.pptx

ETHOS Workshop/Teacher (11-15 years):

- Defining the Friendship: http://www.ethics-education.eu/tools/D9_Friendship_11-15_Teacher\%20Manual_Defining\%20the\%20Friendship.pdf

- Valeria and a Pearl: http://www.ethics-education.eu/tools/D9_Moral\%20Values 11-15 Teacher\%20Manual Valeria $\% 20$ and $\% 20 \mathrm{a} \% 20$ Pearl.pdf; Thinking story: http://www.ethics-education.eu/tools/D7

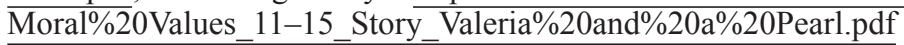

- Online Discussion about Respect: http://www.ethics-education.eu/tools/ D9_Respect_11-15_Teacher\%20Manual_Online \%20Discussion $\% 20 \mathrm{abou}$ t\%20Respect.pdf

- A Fully Unexpected Event in Almond Street No. 31: http://www.ethicseducation.eu/tools/D9 Responsibility_11-15 Teacher\%20Manual_A\% 20Fully\%20Unexpected\%20Event $\% 20$ in $\% 20$ Almond $\% 20$ Street $\% 20$ No. \%2031.pdf; Story: http://www.ethics-education.eu/tools/D9_Responsibility_11-15_Story_A\%20Fully\%20Unexpected $\% 20$ Event $\% 20$ in $\% 20$ Almo nd $\% 20$ Street $\% 20$ No. $\% 2031 . p d f$

- Defining the Tolerance: http://www.ethics-education.eu/tools/D9 Tolerance 11-15_Teacher\%20Manual_Defining\%20the\%20Tolerance.pdf

Antonio Kovačević, "BEAGLE - About the project". Available at:

https://beagleproject.eu/about/

LITTLE online course for teachers in methodologies related to Ethical Education. Available at: http://www.ethicaleducation.eu/resource1.htm

Thomas Pfeil, Harry Underwood, Bruno Ćurko, Franz Feiner, Svenja Pokorny, Pier Giacomo Sola, Eduardo Linares, Begoña Arenas, Marija Kragić, Vojko Strahovnik (2017), Ethics and values education in schools and kindergartens - Policy paper. Available at:

http://www.ethics-education.eu/resources/Ethika_Policy_Paper_EN.pdf

Elvira Sánchez-Igual, Eduardo Linares, Begoña Arenas, Bruno Ćurko, Kyriakos Lingas, Michael Zwanziger, Zsófia Pál, Elena Xeni, Éva Szalma, Svenja Pokorny, Peir Giacomo Sola, Mateja Centa, Marija Kragid, and Vojko Strahovnik; coordination: M. Begoña Arenas, Short report on the state of the art of values education learning for ECEC and primary education teachers. Available at: http://valueseducation.odl.org/wp-content/uploads/2018/09/ AVAL_IO1_REPORT_FINAL.pdf

Evelyn Schlenk, Bruno Ćurko, Franz Feiner, Janez Juhant, Svenja Pokorny, Vojko Strahovnik (2014), A manual for teachers and educators to support the development of educational materials and tools for ethical education. Available at http://www.ethics-education.eu/resources/D6_Methodology_Guidelines.pdf 
Evelyn Schlenk, Kerstin Kreß, Thomas Pfeil (2015), Ethics and value education - Existing state of the art and user needs analysis. Summary report. Available at: http://www.ethics-education.eu/resources/StateOfTheArt-UNA_EN.pdf

TRACE project website: http://www.trace-portal.eu

\title{
EUROPSKI PROJEKTI POVEZANI S ETIČKIM OBRAZOVANJEM U OSNOVNIM I SREDNJIM ŠKOLAMA
}

\author{
Bruno Ćurko, Antonio Kovačević
}

Kroz program Erasmus+, u Ključnoj aktivnosti 2 - "Strateška partnerstva u području obrazovanja i osposobljavanja (KA2)" - Udruga "Mala filozofija" provela je ili upravo provodi ukupno sedam projekata koji su usko vezani uz etičko obrazovanje. Tu valja pridodati i projekt "ETHOS: Ethical Education in Primary and Pre-Primary Schools for a Sustainable and Dialogic Future”, koji je uspješno proveden pod programom Comenius od 2012. do 2014. godine. Karakteristika je ovih projekata usmjerenost na obrazovanje u vrtićima te osnovnim i srednjim školama. Uz "Malu filozofiju”, u projektima sudjeluju sveučilišta, osnovne i srednje škole, vrtići, udruge i institucije iz trinaest zemalja (Austrija, Njemačka, Slovenija, Italija, Španjolska, Mađarska, Bosna i Hercegovina, Grčka, Irska, Nizozemska, Slovačka, Latvija i Hrvatska). Navedeni Erasmus + KA2 projekti su: ETHIKA Ethics and Values Education in Schools and Kindergartens (2014.-2017.), LITTLE - Learning Together to Live Together: Teachers Leading Ethical Education for an Inclusive Society (2016.-2019.), AVAL - Added Value Learning for Preschool Teachers \& Pedagogical Coordinators (2017.-2019.), COMET-A Community of Ethics Teachers in Europe (2017.-2020.), Integrating Ethics of Sport in Secondary School Curriculum (2017.-2019.), BEAGLE - Bioethical Education and Attitude Guidance for Living Environment (2018.-2020.), TRACE - Traditional Children's Stories for a Common Future (2018.-2020.). U članku ćemo ukratko prikazati projektne aktivnosti u navedenim projektima, s posebnim naglaskom na materijale koji su namijenjeni odgajateljima, nastavnicima i učenicima.

Ključne riječi: etičko obrazovanje, Erasmus+ projekti, etika, formalno i neformalno obrazovanje 